\title{
イノベーション政策と情報知識学
}

\section{Innovation policy and information and knowledge science}

\author{
梶川裕矢* \\ Yuya KAJIKAWA
}

東京大学大学院工学系研究科

Graduate School of Engineering, The University of Tokyo

于113-8656 東京都文京区弥生2-11-16工学部9号館

E-mail:kaji@ipr-ctr.t.u-tokyo.ac.jp

世界各国におけるイノ゙ーション政策の強化と, グローバリゼーションの加速の中で, 科学的な知 識や手法に基づき, 政策を立案, 実施, 評価することの重要性が増している. 特に, 情報量が爆発 的に増大する一方, それぞれの専門領域が細分化する状況下において, 情報知識学が果たすべき 役割は大きい. 本講演では, 情報知識学が果たし得る役割と, 今後の課題を議論する.

There is an increasing importance to design, implement, and evaluate policy based on a scientific knowledge and methodology in circumstance of globalization and empowerment of innovation policy. Especially, in information flood and segmentation of disciplines, information and knowledge science should play an important role. In this contribution, the role and remaining issues are discussed.

キーワード: 科学技術, イノベーション, 政策, 情報知識学, 人材

Science and technology, innovation, policy, information and knowledge science, talent

\section{1 緒言}

世界各国におけるイノベーション政策の強化 と, グローバリゼーションの加速の中で, 科学的 な知識や手法に基づき, 政策を立案, 実施, 評 価することの重要性が増している. 米国では, イ ノベーション政策の強化と併行して, マーバー ガー前大統領科学顧問が，「今日のグローバル で技術を基盤とした社会の, 複雑なダイナミズ ムを理解するために,「科学イノベーション政策 の科学」を振興する必要がある」と述べ, 米国科 学財団が,

その方法論の開発のための研究助成を行って
いる. 2008 年には省庁横断型タスクグループ により「科学技術イノベーション政策の科学」に 関する報告書が取りまとめられている. また, 我 が国においても, 同領域において科学的な取 組を強力に促進することの重要性・必要性が認 識され始めている.

科学技術イノベーション政策の科学は, イノベ ーションと科学技術の理解や, 科学技術への投 資効果のモデル化, 国家の研究開発戦略の立 案やプライオリティの設定, さらには, 以上のこ とを可能とする科学的な手法の開発を通じ, エ ビデンスベースの政策立案, 実施, 評価を可能 とすることを目的としている. 特に, 重要なのが, 
科学的な手法の開発であり, 同報告書の中で は, 経済学や社会学と並んでネットワーク分析 や情報の可視化といった情報学が, 今後, 特に 優先的に研究開発を実施すべき領域として取り 上げられている。

\section{2 情報知識学の役割}

ではなぜ情報学が注目されているのだろうか. それには, 情報量が爆発的に増大する一方, それぞれの学術領域が細分化しており, 適切な 科学技術政策を立案しようにも, 全体像が把握 できなといら問題意識にあるものと思われる. 従 って, ネットワーク分析や可視化などを通じて, 科学技術の全体像を俯瞰的に把握する手法を 提供するとともに, データマイニング等の手法に より, 膨大な情報の中に埋もれている有用な情 報を抽出, 分析し, 政策立案者に提供する, ま たそのための手法を開拓することが, 科学技術 イノベーション政策の科学の文脈において, 情 報知識学の果たすべき役割と言えるであろう.

現在, デジタル形式での情報の蓄積が進む につれ, 膨大なデータ群から有用な情報を抽 出しユーザーに提示する, データマイニングに 対する期待が高まっている. データマイニング の手法としては, 統計分析や機械学習, パター ン認識等があるが, 科学技術の主要な成果物 である, 書籍や論文, 特許といった文書群を扱 う上で特に重要なのが, テキストデータを分析 対象とするテキストマイニングと, テキスト間の関 係性を対象とするリンクマイニングである.

上記の手法を活用することで, 例えば, 下記 の様なことが可能である[1].

\section{1 領域全体の構造の俯瞰}

引用分析などを用いることで, 人が把握する のが困難な広大な領域, 例えば, 数万から数十 万，場合によってはそれ以上の論文数からなる 領域の俯瞰を行うことができる. 特にクラスタリン
グと可視化を組み合わせるのが俯瞰に有効で ある. 学術論文を対象にした分析ツールは, 特 許を対象にしたパテントマップ作成ソフトのよう に, 商用のツールが多くあるわけではないが, 多くの学術的な蓄積がある. 我が国においても 科学技術政策研究所により引用分析を用いた サイエンスマップが発表されている[2].

\section{2.萌芽的領域の検出}

領域全体の構造の俯瞰は, 引用分析の応用 として一般的であるが，目的を持たずにただ俯 瞰しても何も浮かび上がってはこない. 何かが 分かったような気になるだけである. 俯瞰の目 的として, 特定の領域から, 今まさに産まれ成 長しつつある萌芽的な領域を抽出することは, 俯瞰をすることの意義として実用上重要であり， かつその手法は実用に耐えうるレベルに達して いる $[3,4]$.

既存の検出法は基本的には時系列データの クラスタリングに基づいている. 膨大な量の文献 からなる引用ネットワークの発展のダイナミクス を分析することで, 現在, どの領域が注目され ているか, また, その領域は従来の領域の延長 線上にあるのか, もしくは既存の分野の枠に収 まることなく, 新たな領域を切り開いている分野 かといったことを判断することができる. 従来, 研究者や政策立案者の直感や感覚に頼ってい たそのような判断を, 客観的, 定量的な手法を 用いて見える化することで, 政策立案者に対し て, 説得力のあるデータを示し, 意思決定に用 いることができる.

\section{3. 重要な論文の予測}

科学技術政策, イノベーション政策を適切に 立案する上では, 科学技術の現状の記述だけ でなく, 将来に対する視点を提供することが求 められる. 重要な論文の代理指標として, 被引 用数を用いることが許されるならば, ネットワー ク分析や機械学習を用いた引用予測が可能と 
なる. 引用予測には 2 通りのアプローチがある. すなわち, 静的なアプローチと動的なアプロー チである.ここで静的とは出版年のような時間の 情報を含まないといらことであり, ある時点での 任意の論文間の引用の有無を予測するというこ とである. 動的な予測とは過去の情報を用いて， 未来を予測することである. 例えば, 現在の引 用ネットワークの情報を用いて, 将来の被引用 数を予測できれば, 既に現在注目されている領 域を検出するのではなく, 現在はほとんど注目 されていないが, 将来, 重要となるであろう論文 を予測することが可能である[5].

\section{4. コーパス間の差異の抽出}

コーパス間の差分の分析, すなわち, 論文の 情報と特許の情報, ウェブの情報と新聞記事の 情報といら風に異なるコーパスの間の違いをみ ることということは, 情報知識学において, 従来, ほとんじ研究対象となってこなかったが，そのよ うな分析を行うことで, 有用な示唆が得られる場 合がある. 例えば, 論文の引用ネットワークの構 造と, 特許の引用ネットワークの構造の間の差 異を抽出することで, 学術研究の中では活発に 研究されているが, 特許はあまり出願されてい ない, 産業界からみれば機会と捉えられる領域 や, 特許は多く出願されているが学術的にはほ とんど顧みられていない領域を抽出するといっ たことが可能である[6].

\section{3 今後の課題}

科学技術イノベーション政策の科学, ならび に, そこでの情報知識学の貢献はまだ始まった ばかり，これから始まろうとするところである. 前 節でみた応用以外にも様々な貢献が今後期待 できる.しかし, 単に研究に留まるのではなく, 科学技術政策, イノベーション政策に有用なも のとなるためには, 下記の点等に注意する必要 がある $[7,8]$.

\section{1. ツールの提供}

一点目は基礎技術だけでなく, それらを組み 合わせ, インターフェースを整備したツールとし て提供すべきであるということである. 政策立案 者などのステークホルダーがそれぞれの基礎 技術の良し悪しを判断し, 実装し, 分析まで行う のは現実的ではない. 研究者は基礎研究を行 うだけでなく, 得られた成果を実装し, 分析ツー ルとして提供する, もしくは, 分析結果を提供す る,さらには, 結果から導き出されるインプリケ ーションや, 国に対するアドバイスや提言まで 踏み込んで行うべきであろう.ただし，上記の 様々なタスクを, 大学, 国研, シンクタンク等で どのように役割分担をするのかといった議論は 必要であろう。

\section{2. 情報開示之機密性}

二点目は情報開示と機密性の問題である. 科学技術イノベーション政策のツールについて は,そこから得られた結果やッールを何処まで 公開するかが, 将来的には問題になると考えら れる. 科学技術の状況の実時間観測や予測の 結果は, 政策を決定する際の要となる情報で あり, 機密性が重要となる. 一方で, 科学として の進展を考えるのであれば, 結果やッールは 広く使用されることが望ましいであろう. 機密性 と開示性, この両者のバランスについても, 科 学技術イノベーション政策のための科学を推進 する上で考えていく必要があるであろう.

\section{3. エビデンスと戦略}

三点目は, 分析結果の乱用や誤用を防ぎ, 分析結果をもとに戦略へと昇華する能力をい かに養成するかということである. 情報知識学 における分析は, 論文や特許, Web情報など の明示的な情報に基づくことが多い. 従って得 られた結果は過去から現在にわたる情報をも とに導き出されたものである. ネットワーク分析 等の手法により, 萌芽的研究領域や, 将来の 
有望領域を抽出できたからと言って，そこに投 資すべきということにはならない. エビデンスは 戦略を決定するものではなく, 戦略を立案する 基盤となる情報である. 今後より一層多くなる 情報(シェアやランキングなど)に踊らされるこ とが無いように, 関係者に対してある程度デー タを読む力を啓発していく機会を持つべきであ ろう. この点に関しては, 経済学や経営学等の 他領域から得られた知見を最大限活用すべき である.

\section{4. 情報知識学の人材育成を}

最後に情報知識学分野の人材育成の重要 性について触れたい. 科学技術イノベーション 政策の科学のための分析手法に関する研究動 向の調査[8]によると, 我が国は, Web工学やデ ータマイニング, ネットワーク分析といった論文 数が伸びている領域において一定程度の競争 力を有しているも.しかし, 論文数のシェアは世 界の 1 〜\%程度であり, 特に図書館情報学の分 野では極端に論文数が少ない.これは研究者 の数が極端に少ないこと, 内向き志向であり, 国内でのみ活動していることに起因していると 思われる. 従って, 今後, 世界に伍して研究開 発を行うとためには, 情報知識学分野における 有力な研究者に対し, 科学技術イノベーション 政策の科学への参入を促す必要があるだけで なく, 研究教育拠点を設置するなど, 研究者の 総数を増やす工夫を測る必要がある.

\section{参考文献}

[1] 梶川裕矢:「リンクマイニングを用いた引用 情報の活用」，情報の科学と技術，Vol.60, pp.224-229, 2010.
[2] 伊神正貫; 阪彩香:「サイエンスマップによ る科学研究の動的変化の観測-手法と応用」, 情報管理, Vol.52, No.5, pp.255-266, 2009.

[3] Shibata, N.; Kajikawa,Y.; Takeda,Y.; Matsushima,K: "Detecting emerging research fronts based on topological measures in citation networks of scientific publications", Technovation, Vol.28, No.11, pp.758-775, 2008.

[4] Kajikawa,Y.; Yoshikawa,J.; Takeda,Y.; Matsushima,K: "Tracking emerging technologies in energy research: toward a roadmap for sustainable energy", Technological Forecasting and Social Change, Vol.75, No.6, pp.771-782, 2008.

[5] Shibata,N.; Kajikawa,Y.; Matsushima,K.: "Topological analysis of citation networks to discover the future core papers", Journal of the American Society for Information Science and Technology, Vol.58, No.6, pp.872-882, 2007.

[6] Shibata,N.; Kajikawa,Y.; Sakata,I: "Extracting the commercialization gap between science and technology - Case study of a solar cell-“, Technological Forecasting and Social Change, Vol.78, pp.274-282, 2010.

[7] 伊神正貫; 阪彩香; 梶川裕矢：「科学技 術知識のマッピング研究の現状と今後の課題」, 研究・技術計画学会年次学術大会講演要旨集, Vol.25, pp.825-828, 2010.

[8] 梶川裕矢; 坂田一郎：「科学技術イノベー ション政策の科学のための分析手法の動向」 研究・技術計画学会年次学術大会講演要旨集, Vol.25, pp. 818-821, 2010. 